\title{
Habit of cooking pork on hot stones as main risk of cysticercosis
}

\author{
Semuel Sandy*, Antonius Oktavian*, Hanna S Kawulur*, Mirna Widiyanti*, \\ Iman HS Sasto*, and Yustinus Maladan*
}

\begin{abstract}
BACKGROUND
Cysticercosis is an infectious disease caused by the larval form of Taenia solium (cysticercus cellulosae) and has been ranked as the most important food-borne parasite of humans in terms of public health, socioeconomic and trade impact. Cysticercosis is still a health problem in Papua and is inseparable from socio-cultural factors, hygiene and environmental sanitation. The aim of this study was to investigate the seroprevalence of cysticercosis and the risk factors that contribute to cysticercosis.
\end{abstract}

\section{METHODS}

A cross-sectional study was conducted in March-November 2016 involving 800 subjects. Demographic data and risk factors were collected using questionnaires. Cysticercosis serological examination was performed by means of the magnetic microsphere bead immunoassay technique coupled with rT24H recombinant protein to detect serum rT24H cysticercosis specific antibodies. The data obtained were analyzed by bivariate test (chi-square) and logistic regression.

\section{RESULTS}

Cysticercosis seroprevalence in Papua was 3.6\% (284/7 874). The logistic regression analysis found that the risk factors playing the role of predictor were cooking pork with hot stones [OR=3.06; 95\%CI: 2.19-4.28; $\mathrm{p}=0.000]$, nail hygiene $[\mathrm{OR}=2.05 ; 95 \% \mathrm{CI}: 1.57-2.67 ; \mathrm{p}=0.000]$, consumption of raw vegetables or salads [OR $=0.52 ; 95 \% \mathrm{CI}: 0.30-0.91 ; \mathrm{p}=0.022]$, use of river water for washing foods $[\mathrm{OR}=1.92 ; 95 \% \mathrm{CI}$ : $1.39-2.64 ; \mathrm{p}=0.000]$.

\section{CONCLUSIONS}

Cooking pork with hot stones was the main risk factor of cysticercosis. Suspected cases of T. solium in pigs should be confirmed by molecular methods. Both taeniasis and human cysticercosis should be notifiable and surveillance in animals should be improved.

Keywords: Seroepidemiology, cysticercosis, Taenia solium, pork, Papua

\author{
*Papua Biomedical Research and \\ Development Station (Balai Litbang \\ Biomedis Papua)
}

\section{Correspondence :}

Semuel Sandy

Balai Litbang Biomedis Papua

J1. Kesehatan No.10 Dok II.

\section{Jayapura}

Email: mercury.sandy56@gmail.com)

Mobile: +6281527644234

Date of first submission, December 28, 2017

Date of final revised submission,

August 2, 2018

Date of acceptance, August 6, 2018

This open access article is distributed under a Creative Commons AttributionNon Commercial-Share Alike 4.0 International License

\section{Cite this article as: Sandy S, Oktavian A, Kawulur HS, et al. Habit of cooking pork on hot stones as main risk of cys- ticercosis. Univ Med 2018;37:88-96. doi: 10.18051/UnivMed.2018.v37.88- 96}




\section{INTRODUCTION}

Cysticercosis is a parasitic infectious disease caused by the larval stage of Taenia solium that can attack human tissues or organs such as the muscles, eyes, heart, lungs, and brain. ${ }^{(1)}$ The sources of cysticercosis transmission are patients with $T$. solium taeniasis, where the stools of the patients that contain the tapeworm eggs contaminate the environment, and if the eggs are ingested they can cause cysticercosis in pigs as well as in humans. Cysticercosis in the subcutaneous tissues can be observed by the formation of subcutaneous nodules, while in the brain the presence of $T$. solium cysts cause neurocysticercosis with epileptic seizures as the most frequent sign. ${ }^{(2,3)}$

Neurocysticercosis is a public health problem in developing countries. The presence of $T$. solium cysts in the brain results in a disorder of the central nervous system, causing secondary epilepsy in the majority of patients. Neurocysticercosis has been reported as the cause of around 20-50\% of secondary epilepsy in several countries in the world. ${ }^{(4)}$ The incidence of taeniasis/cysticercosis is highest in Africa, Southeast Asia, Central and South America, and Europe. ${ }^{(3,5)}$ In the Southeast Asian region research has been conducted on the prevalence of taeniasis and cysticercosis, e.g. in Indonesia, the Philippines, Singapore, Vietnam and Burma. In Indonesia, endemic areas of $T$. solium are West Irian, North Sumatra, Bali, Flores and Timor. ${ }^{(6)}$ However, taeniasis/cysticercosis has also been reported in Lampung, Jakarta, East Java, East Nusa Tenggara, West Kalimantan, East Kalimantan, North Sulawesi, South Sulawesi and Southeast Sulawesi. ${ }^{(7)}$

Taeniasis/cysticercosis in Papua was initially encountered in the Paniai district in 1970-1972, then spread to the regions East of the Jayawijaya mountain range into Baliem Valley and other districts, including the districts of Jayawijaya, Tolikara, Puncak Jaya, Pegunungan Bintang, and the areas bordering Papua New Guinea (PNG). ${ }^{(7,8)}$ The prevalence of cysticercosis in the
Papua mountains is around $20.8 \%$, while the prevalence of taeniasis is $7 \%{ }^{(9)}$

Humans are infected with taeniasis because of consumption of undercooked or raw $T$. solium larvae-containing pork, while cysticercosis occurs due to human consumption of food or water contaminated with T. solium eggs. Cysticercosis may also occur from autoinfection in patients with taeniasis. ${ }^{(5)}$ A study on the risk factors of taeniasis/ cysticercosis in Vietnam reported that consuming undercooked or raw pork, raw vegetables or salads, and unboiled water are important positive factors for the spread of the disease, whereas hand washing with soap before meals and after defecation is important in its prevention. ${ }^{(10)}$ The risk factors of taeniasis/cysticercosis transmission in Africa, Asia, Latin America, and Southeast Asia are generally similar, i.e. community culture, poor environmental sanitation, low level of personal hygiene, low educational level, free-roaming pigs, consumption of undercooked or raw pork, and consumption of raw vegetables or salads. ${ }^{(5,10)}$ Similarly, the risk factors of taeniasis/cysticercosis transmission in Papua are associated with the consumption of undercooked pork and vegetables, low educational level on hygiene, and free-roaming pigs. ${ }^{(11)}$ However, there is a need for further study on the management of pork consumption. The aim of this research was to determine the risk factors that are important predictors of cysticercosis in humans.

\section{METHODS}

\section{Research design}

This was a cross-sectional research project of the Papua Biomedical Research and Development Station (Balai Litbang Biomedis Papua) that was conducted in March 2016 in 10 districts of Papua Province, i.e. the districts of Biak Numfor, Paniai, Nabire, Deiyai, Nduga, Intan Jaya, Jayawijaya, Yalimo, Mamberamo Pusat, and Lannya Jaya. The reason why these 10 districts were selected was because historically the initial cases of taeniasis and cysticercosis were found in the Paniai district, 
then spread to the East to Pegunungan Bintang district, while to the West they spread to the districts of Deiyai, Nabire, Teluk Wondama and Manokwari (Figure 1).

\section{Research subjects}

The research subjects were respondents above the age of 5 years from among the residents who were domiciled around pig farms. Sample collection was performed by purposive sampling by considering community spots of pig farmers.

The size of the research sample was calculated by the Central Agency for Statistics of Papua Province (Badan Pusat Statistik Provinsi Papua), using the cross-sectional study equation with consideration of the design effect of the study. ${ }^{(12)}$ The prevalence (p) of cysticercosis in Papua was 20-25.6\% (based on considerations of the Papua Province Animal
Breeding and Health Service (Dinas Peternakan and Kesehatan Hewan Provinsi Papua), with a margin of error (E) of $20 \%$, confidence interval of $95 \%(95 \% \mathrm{CI})$, mean household population (x) of 4 persons, anticipated drop-outs of $5 \%$, and research design effect (deff) of 2.

$$
\mathrm{n}=\frac{\mathrm{z}^{2} \mathrm{p}(1-\mathrm{p})(\text { deff }) \times 1.05}{\mathrm{EP}^{2} \times \mathrm{k}(\mathrm{X})}
$$

Therefore the study sample size was 800 individuals.

\section{Data collection}

Collection of demographic data and risk factors was performed by means of questionnaires, comprising the respondents' gender, education, habit of washing hands with water and soap before meals, habit of washing

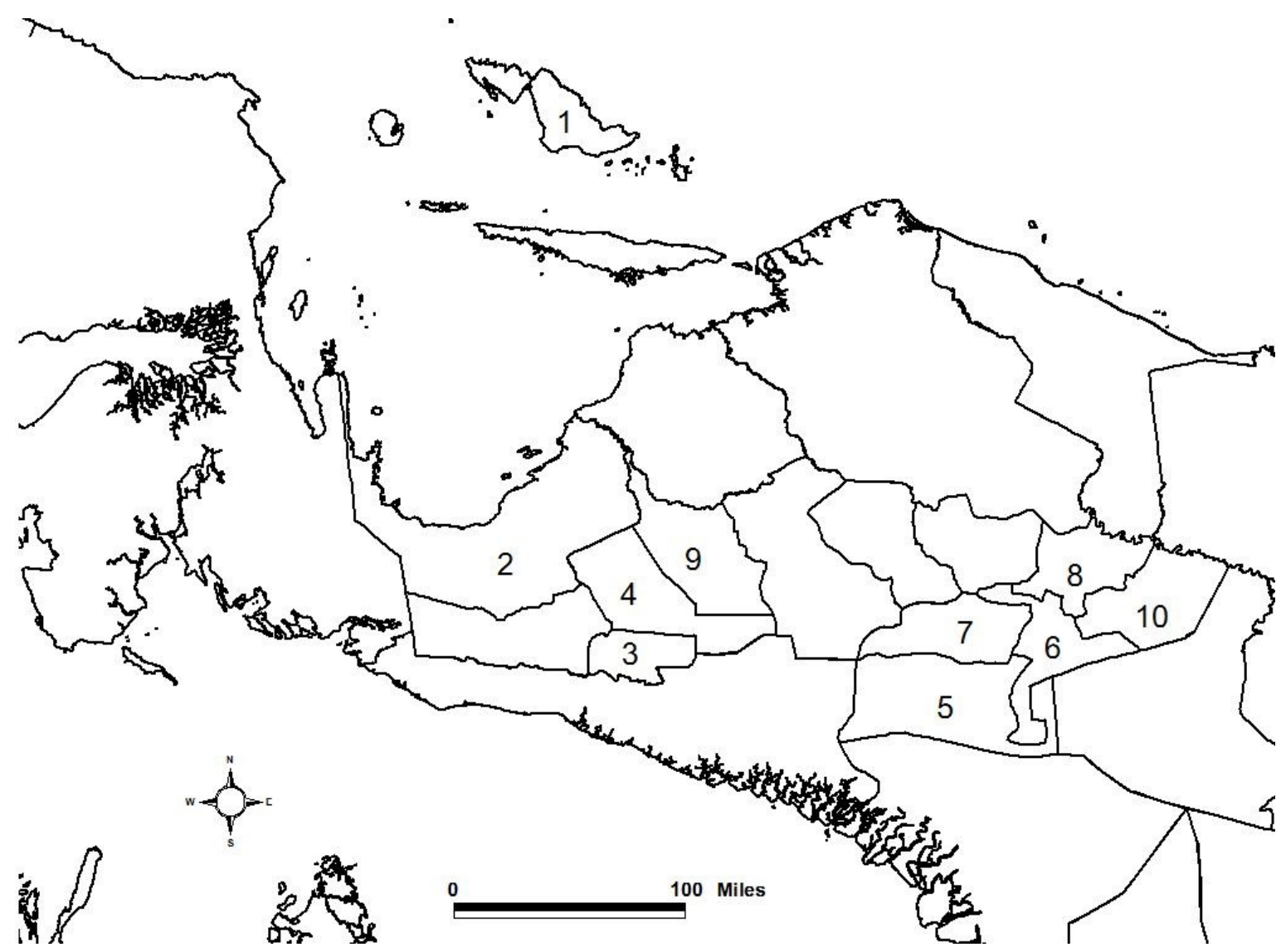

Figure 1. Cysticercosis sero-epidemiologic locations and sample size by district, Papua 2017. Legend: 1. Biak Numfor $(n=800), 2$. Nabire $(n=798), 3$. Deiyai $(n=798), 4$. Paniai $(n=800), 5$. Nduga $(n=797), 6$. Jayawijaya $(n=799), 7$. Lannya Jaya $(n=800)$ 8. Mamberamo Tengah $(n=800)$. 9. Intan Jaya $(n=800)$, 10. Yalimo $(n=682)$ 
hands with water and soap after defecation, nail hygiene, source of water for washing vegetables, consumption of raw vegetables, and habit of using hot stones for cooking pork. Interviews with 5-12 year-old respondents were performed in the presence of their parents or of adults residing in the same house.

\section{Laboratory assay}

The diagnosis of cysticercosis was established by drawing a blood sample of 4 drops (an estimated $400 \mu \mathrm{l}$ of blood sample) from the fingertips of the respondents using Whatman grade No.3 filter paper that was then dried and placed in silica gel-containing plastic bags. Serologic assays of serum specimens were performed by means of magnetic microsphere bead immunoassay for detection of specific circulating antibody against the recombinant cysticercosis protein rT24H using MagPix Luminex equipment. ${ }^{(13)}$ The assay was a multiplex assay using the cysticercosis protein antigen rT24H (Genscript Lot.\# U7761BI2801) on microsphere beads according to the Luminex protocol.

The samples were prepared using the Luminex Immunoassay technique ${ }^{(14,15)}$ i.e. the blood sample on filter paper was dissolved in 1 x PBS solution (Sigma, Cat.\# P4417-100 tab); 0.3\% Tween-20 (Sigma, Cat.\# P1379 100 ML) and $0.1 \% \mathrm{NaNO}_{3}$ (HiMedia, Cat.\# GRM1038), so that the sample concentration was $1: 10$. A volume of $50 \mu \mathrm{L}$ rT24H magnetic microsphere mixture $(50 \mu \mathrm{L}$ microparticles $/ \mu \mathrm{L}$ in $1 \mathrm{x}$ PBS; $0.3 \%$ Tween-20; $5 \%$ skim milk) was pipetted and placed in round-bottomed microplate wells (Costar, Cat.\# 3792). Subsequently $50 \mu \mathrm{L}$ of the sample was added to the wells (sample concentration 1:100 in $1 \times$ PBS; $0.3 \%$ Tween$20 ; 5 \%$ skim milk) and incubated at room temperature for 30 minutes using the microplate shaker (800 rpm). Washing with PBS $1 \mathrm{x} ; 0.3 \%$ Tween-20 was performed twice manually using Luminex magnetic microplate washer. Binding of the recombinant rT24H protein complex with specific circulating antibody was detected by adding $50 \mu \mathrm{L}$ biotinylated mouse anti-IgG4 (Clone HP6025, affinity purified, Southern Biotech, Birmingham, AL, Cat.Number 920008) dissolved in $1 \times$ PBS, $1 \%$ BSA, $0.05 \%$ $\mathrm{NaNO}_{3}$ (concentration 1:200) then incubated for 30 minutes on the microplate shaker ( $800 \mathrm{rpm})$. Subsequently washing was done 3 times then detection of the fluorescent color was performed by adding $50 \mu \mathrm{L}$ R-phycoerythrin-labeled streptavidin conjugate [(Invitrogen, Cat.\# S866) dissolved in 1x PBS-1\% BSA, 0.05\% (Sigma Cat.\# A9647-10 g) $\mathrm{NaN}_{3}$ so that the concentration was $1: 250$ ] then incubated for 30 minutes. After incubation washing was done 3 times then the mixture was suspended in 125 $\mu \mathrm{L} 1 \mathrm{x}$ PBS, $1 \% \mathrm{BSA}, 0.05 \% \mathrm{NaNO}_{3}$, and the median fluorescence intensity (MFI) was read on the MagPix Luminex using the Luminex software $4.0 .^{(16)}$ Data validity control was performed with recombinant $\mathrm{rT} 24 \mathrm{H}$ antigen as cysticercosis antigen standard.

The data were interpreted by observing the data output of the Luminex MagPix in the form of MFI values and quantitative data of magnetic beads that had reacted. The sera of patients with positive cysticercosis were used as cysticercosis positive controls. The cut-off value was determined using cysticercosis-negative serum, by measuring the mean MFI and its standard deviation (SD), where eventually the cut-off value $=$ mean $\mathrm{MFI}+2 * \mathrm{SD}$ of the MFI negative standard. The serologic assay results were interpreted as positive if the MFI > cut-off value, then the cysticercosis serologic score was determined $(0=$ negative cysticercosis, $1=$ positive cysticercosis) for logistic regression analysis.

\section{Statistical analysis}

The collected questionnaire data were processed using Epi Data ver. 3.1, then bivariate screening analysis was done with Chi-square test at significance of $p<0.05$, followed by logistic regression analysis to determmine the causal predictors of cysticercosis in the community at $95 \%$ confidence level and significance of $\mathrm{p}<0.05$. 


\section{Ethical clearance}

This research obtained ethical clearance from the Health Research Ethics Commission of Badan Litbangkes under No. LB.02.01/5.2/ KE.086/2016.

\section{RESULTS}

The laboratory test results for 7,874 serum samples showed that the cysticercosis seroprevalence in Papua was 3.6\%. The highest seroprevalence was found in Memberamo Tengah district $(16.0 \%)$, followed by Nduga $(6.9 \% ; 55 / 797)$, Yalimo (4.0\%; 27/682), Nabire $(2.6 \% ; 21 / 798)$, Paniai $(2.4 \% ; 19 / 800)$, Lannya Jaya $(1.6 \% ; 13 / 800)$, Jayawijaya $(0.9 \% ; 7 / 799)$, Biak Numfor $(0.8 \% ; 6 / 800)$, Intan Jaya $(0.8 \%$; $6 / 800)$, and Deiyai $(0.3 \% ; 2 / 798)$ (Table 1).

The relationship between risk factors and cysticercosis in the 10 districts of Papua may be seen in Table 2 .

Table 2 shows that there was a significant relationship of educational level, nail hygiene, vegetable salads, use of river water for washing vegetables, and cooking pork on hot stones with the incidence of cysticercosis $(p<0.05)$. The significant risk factors were education $(\mathrm{p}=0.041)$, nail hygiene $(p=0.021)$, consumption of raw vegetables or salads $(\mathrm{p}=0.049)$, river as water source $(\mathrm{p}=0.000)$, and cooking pork on hot stones $(\mathrm{p}=0.000)$, which were further analyzed by logistic regression, for determining which risk factors constituted causal predictors of cysticercosis in the community. The results of the logistic regression analysis may be seen in Table 3 .
Table 3 shows that cooking pork on hot stones constituted the greatest risk factor for the occurrence of cysticercosis $(\mathrm{OR}=3.06 ; 95 \%$ C.I. 2.19-4.28).

\section{DISCUSSION}

The results of this study shows that the cysticercosis seroprevalence in Papua was $3.6 \%$. This does not differ much from the results of previous studies in several districts in the central mountain range of the Papua Province, where the seroprevalence in Puncak Jaya and Pegunungan Bintang was 2-2.6\% and in the Paniai and Jayawijaya districts 20.8-29.2\%. ${ }^{(17)}$ On-location observation of the respondents' hygiene still found dirty and long fingernails. The results of logistic regression analysis shows a significant relationship between nail hygiene and incidence of cysticercosis [OR $=2.05 ; 95 \%$ C.I. 1.57-2.67). These results show that dirty fingernails carry a 2.05-fold risk of cysticercosis. This is due to the fact that long fingernails will readily accumulate dirt, such as soil, if children play with soil or adults work in their gardens or after defecation if they do not thoroughly wash their hands. Dirt under the fingernails is difficult to remove by hand washing only without picking and removing it. This may be a risk factor for the adherence of T. solium eggs from contaminated soil, so that they can cause cysticercosis. ${ }^{(18)}$ This is also supported by Mwanjali et al. ${ }^{(19)}$ who reported that poor nail hygiene constitutes a risk factor for cysticercosis infection.

Table 1. Cysticercosis seroprevalence by districts in Papua

\begin{tabular}{|c|c|c|c|}
\hline District & $\mathbf{n}$ & Cysticercosis seroprevalence & $\%$ \\
\hline Biak Numfor & 800 & 6 & 0.8 \\
\hline Nabire & 798 & 21 & 2.6 \\
\hline Deiyai & 798 & 2 & 0.3 \\
\hline Paniai & 800 & 19 & 2.4 \\
\hline Nduga & 797 & 55 & 6.9 \\
\hline Jayawijaya & 799 & 7 & 0.9 \\
\hline Lannya Jaya & 800 & 13 & 1.6 \\
\hline Mamberamo Tengah & 800 & 128 & 16 \\
\hline Intan Jaya & 800 & 6 & 0.8 \\
\hline Yalimo & 682 & 27 & 4.0 \\
\hline Total & 7,874 & 284 & 3.6 \\
\hline
\end{tabular}


Table 2. Relationship between several risk factors and cysticercosis

\begin{tabular}{|c|c|c|c|c|c|c|c|}
\hline \multirow{3}{*}{ Risk factors } & \multicolumn{4}{|c|}{ Cysticercosis serology } & & & \multirow{3}{*}{ p valu } \\
\hline & \multicolumn{2}{|c|}{ Seropositive } & \multicolumn{2}{|c|}{ Seronegative } & \multicolumn{2}{|c|}{ Total } & \\
\hline & $\bar{n}$ & $\%$ & n & $\%$ & $\mathbf{n}$ & $\%$ & \\
\hline \multicolumn{8}{|l|}{ Gender } \\
\hline Male & 130 & 3.6 & 3493 & 96.4 & 3623 & 100 & \multirow[t]{2}{*}{0.935} \\
\hline Female & 154 & 3.6 & 4097 & 96.4 & 4251 & 100 & \\
\hline \multicolumn{8}{|l|}{ Education } \\
\hline $\begin{array}{l}\text { Low (no schooling, } \\
\text { elementary school) }\end{array}$ & 200 & 3.9 & 4898 & 96.1 & 5098 & 100 & \multirow[t]{2}{*}{0.041} \\
\hline $\begin{array}{l}\text { Middle to high (Junior } \\
\text { high school, senior high } \\
\text { school, D1, D2, D3, S1) }\end{array}$ & 84 & 3.0 & 2692 & 97.0 & 2776 & 100 & \\
\hline \multicolumn{8}{|l|}{$\begin{array}{l}\text { Hand washing with water } \\
\text { and soap before meals }\end{array}$} \\
\hline No & 156 & 3.6 & 4230 & 96.4 & 4386 & 100 & \multirow[t]{2}{*}{$0.78 \varepsilon$} \\
\hline Yes & 128 & 3.7 & 3359 & 96.3 & 3487 & 100 & \\
\hline \multicolumn{8}{|l|}{$\begin{array}{l}\text { Hand washing after } \\
\text { defecation }\end{array}$} \\
\hline No & 162 & 3.6 & 4342 & 96.4 & 4504 & 100 & \multirow[t]{2}{*}{0.954} \\
\hline Yes & 122 & 3.6 & 3247 & 96.4 & 3369 & 100 & \\
\hline \multicolumn{8}{|l|}{ Nail hygiene } \\
\hline Not clean & 184 & 3.3 & 2192 & 96.7 & 5582 & 100 & \multirow[t]{2}{*}{0.021} \\
\hline Clean & 100 & 4.4 & 5398 & 95.6 & 2292 & 100 & \\
\hline \multicolumn{8}{|l|}{$\begin{array}{l}\text { Vegetables made into } \\
\text { salads or consumed raw }\end{array}$} \\
\hline No & 270 & 3.7 & 6964 & 96.3 & 7234 & 100 & \multirow[t]{2}{*}{0.049} \\
\hline Yes & 14 & 2.2 & 620 & 97.8 & 634 & 100 & \\
\hline \multicolumn{8}{|l|}{ River as source of water } \\
\hline No & 232 & 3.2 & 6960 & 96.8 & 7192 & 100 & \multirow[t]{2}{*}{0.000} \\
\hline Yes & 52 & 7.6 & 630 & 92.4 & 682 & 100 & \\
\hline \multicolumn{8}{|l|}{$\begin{array}{l}\text { Cooking pork on hot } \\
\text { stones }\end{array}$} \\
\hline No & 49 & 1.8 & 2677 & 98.2 & 2726 & 100 & \multirow[t]{2}{*}{0.000} \\
\hline Yes & 235 & 4.6 & 4913 & 95.4 & 5148 & 100 & \\
\hline
\end{tabular}

*p with Chi-square test

The results of our study show that consumption of raw vegetables or salads was a risk factor for cysticercosis. Similar results were obtained in a Laotian study where consumption of uncooked vegetables was a risk factor for cysticercosis. ${ }^{(20)}$ A study by Sah et al. ${ }^{(21)}$ found that the use of river water for consumption was significantly associated with incidence of cysticercosis. A study by Van De et al. ${ }^{(22)}$ in Vietnam reported that the sources of cysticercosis transmission are consumption of raw vegetables and fresh fruit, half-cooked pork, and unboiled drinking water. Unprotected river streams or water wells may become contaminated with T.solium eggs, ${ }^{(23)}$ which can survive in water for long periods of time so becoming a source of

Table 3. Results of multiple logistic regression analysis of risk factors correlated with incidence of cysticercosis

\begin{tabular}{lccccc}
\multicolumn{1}{c}{ Risk factors } & $\boldsymbol{\beta}$ & $\mathbf{p}$ & \multicolumn{2}{c}{$\begin{array}{l}\text { Odds } \\
\text { ratio }\end{array}$} & \multicolumn{2}{c}{$\mathbf{9 5 \%}$ Confidence interval } \\
\hline Cooking pork on hot stones (1) & 1.12 & 0.000 & 3.06 & 2.19 & 4.28 \\
Vegetables made into salads or & -0.64 & 0.022 & 0.53 & 0.30 & 0.91 \\
consumed raw (1) & & & & & \\
River as water source (1) & 0.65 & 0.000 & 1.92 & 1.39 & 2.64 \\
Nail hygiene (1) & 0.72 & 0.000 & 2.05 & 1.57 & 2.67 \\
\hline
\end{tabular}


cysticercosis transmission in pigs and humans. ${ }^{(1,5)}$ Different results were obtained by Nkouawa et al. ${ }^{(24)}$ who reported that there was no significant relationship of the use of river water and vegetable consumption with cysticercosis.

The cooking of pork on hot stones still allows the tapeworm larvae to survive, so that they can cause taeniasis and indirectly constitute a factor in the transmission of cysticercosis if humans consume the half-cooked and taeniasis-infected pork. Patients with taeniasis may become sources of cysticercosis transmission and infect themselves (autoinfection) as well as pigs and humans in their neighborhood. ${ }^{(25)}$ The results of our study show that the risk factor of cooking pork on hot stones has a significant relationship with the prevalence of cysticercosis. This may be because the vegetables and roots that are cooked together with the pork are contaminated with tapeworm eggs from the soil around the cooking site. ${ }^{(28)}$ Consumption of raw or halfcooked T. solium larvae-containing pork is an indirect factor, since it causes taeniasis, which results in contamination of the environment with T.solium eggs, but causes cysticercosis upon autoinfection. This is supported by the study of Khaing et al. ${ }^{(23)}$ who reported that the risk factors of cysticercosis transmission are among others community cooking resulting in consumption of half-cooked or raw meat.

A limitation of this study is its crosssectional design so that it cannot evaluate any cause-and-effect relationships. The collection of the samples was performed on respondents residing near pig farming communities, so that there is a high probability that local respondents residing far from district cities were not included. Interview bias may occur from the large community gatherings at the time of visit to the respondents.

The implication of this study is that there are still cases of taeniasis and cysticercosis to be found in Papua, indicating that there are still neglected diseases in Indonesia, so requiring cross-sectoral management for the prevention and control of disease transmission. The use of the magnetic microbead immunological assay is of great help in doing surveys with large samples, so saving time and expenditure.

Cysticercosis studies or surveys should not only be conducted in humans but also in pigs for early identification of porcine cysticercosis to obtain more epidemiologic data for this disease. The magnetic microbead immunoassay with recombinant $\mathrm{rT} 24 \mathrm{H}$ protein for the detection of serum cysticercosis antibodies in pigs should also be performed. This method requires only small amounts of serum so simplifying the management and transportation of the samples from distant locations.

\section{CONCLUSION}

This study demonstrated that cooking pork on hot stones was the main risk factor for cysticercosis. The main problem for control of cysticercosis lies in reducing the risk factors.

\section{ACKNOWLEDGMENTS}

The authors extend their heartfelt gratitude to the Heads of Badan Litbangkes RI, dr. Sukwan Hamdali, PhD, Dra. Rita M Dewi, MKes, and dr. Masri S Maha, the Heads of Balai Litbang Biomedis Papua, LIMNAS Papua, Provincial Health Service (Dinas Kesehatan Provinsi) and District Health Services in Papua, the Heads of all Puskesmas, community leaders/village heads (Kepala Kampung) and all community members of Papua Province who participated in the study.

\section{CONFLICT OF INTEREST}

There is no conflict of interest in this study

\section{CONTRIBUTORS}

SS and AO contributed to design of the study. HSK, HK, MW, HMH, YES contributed in the survey team and collection of samples; IHSS, YM, IRN, EF performed laboratory 
examinations, SS and YM analyzed and interpreted the data. All authors read and approved the final manuscript.

\section{REFERENCES}

1. Wardrop NA, Thomas LF, Atkinson PM, et al. The influence of socio-economic, behavioural and environmental factors on Taenia spp . transmission in Western Kenya: evidence from a cross-sectional survey in humans and pigs. PLoS Negl Trop Dis 2015;9:1-16. Doi: 10.1371/journal. pntd.0004223.

2. Arriola CS, GonzalezAE, Gomez-puerta LA, et al. New insights in cysticercosis transmission. PLoS Negl Trop Dis 2014;8:8-11. doi: 10.1371/journal. pntd.0003247.

3. Laranjo-gonzález M, Devleesschauwer B, Trevisan C, et al. Epidemiology of taeniosis/ cysticercosis in Europe, a systematic review: Western Europe. Parasit Vector 2017;10:349. doi: 10.1186/s13071-017-2280-8.

4. Winkler AS. Neurocysticercosis in sub-Saharan Africa: a review of prevalence, clinical characteristics, diagnosis, and management. Pathog Glob Heal 2012;106:261-74. doi: 10.1179/ 2047773212 Y.0000000047.

5. Xu JM, Acosta LP, Hou M, et al. Seroprevalence of cysticercosis in children and young adults living in a helminth endemic community in leyte, the Philippines. J Trop Med 2010; Article ID 603174, 6 pages. doi: 10.1155/2010/603174.

6. Suada IK, Swacita IBN, Purba EHB. Seroprevalensi sistiserkosis pada babi lokal yang dipotong di tempat pemotongan babi Penatih, Denpasar. Indones Med Veterinus 2016;5:182-

7. Wandra T, Swastika K, Dharmawan NS, et al. The present situation and towards the prevention and control of neurocysticercosis on the tropical island, Bali, Indonesia. Parasit Vector 2015;8:148. doi: 10.1186/s13071-015-0755-z.

8. Del OH, García HH. Taenia solium Cysticercosis — the lessons of history. J Neurol Sci 2015;359: 392-5. doi: 10.1016/j.jns.2015.08.011.

9. Assa I, Satrija F, Lukman DW, Dharmawan NS, Dorny P. Faktor risiko babi yang diumbar dan pakan mentah mempertinggi prevalensi sistiserkosis. J Vet 2012;13:345-52.

10. Nguyen D, Stevenson MA, Traub RJ. A systematic review of taeniasis, cysticercosis and trichinellosis in Vietnam. Parasit Vector 2017;10: 150. doi: 10.1186/s13071-017-2085-9.

11. Dharmawan NS, Swastika K, Putra IM, et al. Present situation and problems of Cysticercosis in animal in Bali and Papua. J Vet 2012;13:154-62.
12. Levy PS, Lemeshow S,editors. Sampling of populations, methods and applications, 4th ed. New York: John Wiley \& Sons. Inc.;2011.

13. Angeloni S, Cordes R, Dunbar S, et al, editors. MAP cookbook "a collection of methods and protocols for developing multiplex assays with xMAP Technology". $3^{\text {rd }}$ ed. Austin, Texas: Luminex Corporations; 2016.

14. Kerkhof K, Canier L, Kim S, et al. Implementation and application of a multiplex assay to detect malaria-specific antibodies: a promising tool for assessing malaria transmission in Southeast Asian pre-elimination areas. Malar J 2015;14:338. doi: 10.1186/s12936-015-0868-Z.

15. Wiegand RE, Wilkins PP, Pohl J, et al. Development of a luminex Bead Based Assay for diagnosis of toxocariasis using recombinant antigens Tc-CTL-1 and Tc-TES-26. PLoS Negl Trop Dis 2015;9:e0004168. doi: 10.1371/journal. pntd.0004168.

16. Luminex. MAGPIX User Quick Guide $4.2{ }^{\circledR}$. Austin, Texas: Luminex Corporations; 2011.

17. Salim L, Ang A, Handali S, et al. Seroepidemiologic survey of Cysticercosis-Taeniasis in four central highland districts of Papua, Indonesia. Am J Trop Med Hyg 2009;80:384-8.

18. Wale M, Wale M, Fekensa T. The prevalence of intestinal helminthic infections and associated risk factors among school children in Lumame town, Northwest, Ethiopia. J Parasitol Vector Biol 2014;6:156-65. doi: 10.5897/JPVB2014.0159.

19. Mwanjali G, Kihamia C, Vitalis D, et al. Prevalence and risk factors associated with human Taenia solium infections in Mbozi district, Mbeya. PLoS Negl Trop Dis 2013;7:1-8. doi: 10.1371/journal. pntd.0002102.

20. Okello AL, Burniston S, Conlan J V, et al. Prevalence of endemic pig-associated Zoonoses in Southeast Asia: a review of findings from the Lao People 's Democratic Republic. Am J Trop Med Hyg 2015;92:1059-66. doi: 10.4269/ajtmh.140551.

21. Sah K, Poudel I, Subedi S, et al. A hyperendemic focus of Taenia solium transmission in the Banke District of Nepal. Acta Trop 2017;176:78-82. doi: 10.1016/j.actatropica.2017.07.022.

22. Van De N, Le TH, Lien PTH, et al. Current status of taeniasis and cysticercosis in Vietnam. Korean J Parasitol 2014;52:125-9. doi: 10.3347/kjp.2014.52. 2.125 .

23. Khaing TA, Bawm S, Wai SS, et al. Epidemiological survey on porcine cysticercosis in Nay Pyi Taw Area, Myanmar. J Vet Med 2015;2015:1-5. doi: 10.1155/2015/340828.

24. Nkouawa A, Romeo A, Moyou-somo R, et al. Seroprevalence and risk factors of human 
cysticercosis and taeniasis prevalence in a highly endemic area of epilepsy in Bangoua, west Cameroon. Acta Trop 2017;165:116-20. doi: 10.1016/j.actatropica.2015.12.019.

25. Assa I. Kajian Epidemiologi Sistiserkosis Pada Babi Dan Karakterisasi Risiko Daging Babi Bakar Batu Di Kabupaten Jayawijaya Papua [disertasi]. Bogor: Sekolah Paskasarjana Institut Pertanian Bogor; 2012.

26. Coral-Almeida M, Gabriel S, Abatih EN, et al. Taenia solium human cysticercosis: a systematic review of sero-epidemological data from endemic zones around the world. PLoS Negl Trop Dis 2015;9:1-20. doi: 10.1371/journal.pntd.0003919.
27. Fonseca AG, Torgal J, Meneghi D De, et al. One healthness evaluation of cysticercosis surveillance design in Portugal. Front Public Heal 2018;6:1-10. doi: 10.3389/fpubh.2018.00074.

28. Nguyen T, Cheong FW, Liew JWK, et al. Seroprevalence of fascioliasis, toxocariasis, strongyloidiasis and cysticercosis in blood samples diagnosed in Medic Medical Center Laboratory, Ho Chi Minh City, Vietnam in 2012. Parasite Vector 2016;9:486. doi: 10.1186/s13071016-1780-2. 